\title{
Deixis in the Holy Quran Surah Al-Mulk
}

\author{
Ulya Muharrami ${ }^{1, *}$ Rahmad Husein ${ }^{2}$ Siti Aisah Ginting ${ }^{3}$
}

\author{
${ }^{1}$ Universitas Negeri Medan, Medan, Indonesia \\ ${ }^{2}$ Universitas Negeri Medan, Medan, Indonesia \\ ${ }^{3}$ Universitas Negeri Medan, Medan, Indonesia \\ *Corresponding author.Email: ulyamuharrami@gmail.com, rhnapitupulu@yahoo.com, aisah_ginting@yahoo.co.id
}

\begin{abstract}
This study focuses on analyzing deixis in surah Al-Mulk using the theory of deixis proposed by Stephen C. Levinson. Deixis is a part of discourse analysis which is concerning to the context of utterance referring to who is speaking, the time or place of speaking, the gestures of the the speaker or the current location in the discourse. Surah Al-Mulk is the 67 th surah of Holy Qur'an that has 30 verses. All verses of the letter al-Mulk are said to belong to the group of Makkiyah verses (surah which was released in Mecca). Therefore, it contains many deixis. Based on this, the research on the deixis in the translation of surah Al-Muk is necessary to be conducted. There is one problem in this study, what types of deixis are used in the holy quran surah Al-Mulk? This research is aimed to describe the deixis using Levinson theory. The data are the utterances of surah Al-Mulk in the forms of written text, which are then analysed using descriptive qualitative method. The results of the research show the types of deixis that are found in surah Al-Mulk. They are person deixis, place deixis, time deixis, social deixis and discourse deixis. Based on those findings, the researcher suggests the next researcher to make more wonderful and more complete analysis on the same field, because every literary work especially Al-Quran as the source of Moslem has its own uniqueness and contains many deixis.
\end{abstract}

Keywords: Deixis, Surah Al-Mulk, Translation.

\section{INTRODUCTION}

Human necessarily lives in society to communicate one to another. Communication represents the vital and elementary social process in human life. According to Moekijat (1993), "communication is the interchange of information, ideas, attitudes, thought and opinions". A language is used to communicate among people, and it represents the personality and behavior of people itself.

God creates many languages so that every human in the world can communicate with each other to exchange the information in their daily life. The most problem of communication that happen both of the speakers and hearers is when the speakers and hearers get misunderstanding about the meaning of word that related to the context of situation. If the hearer knows the context, the language can be understood clearlyabout what the meaning. To determine the meaning, we know one of the branches of linguistics that called pragmatics.

Pragmatic is a field of linguistics concerned with the use of language in social contexts and the way in which people produce and comprehend meaning through language. Yule (1996) defines pragmatics as "the study of the relationship between linguistic forms and the users of these forms". Through pragmmatics, contextual meaning is exploited and analyzed to discover the "real" meaning.

Hansen and Visconti (2009) stated pragmatic concerned with the redefinition of the respective roles of speaker/writer and address/readers in the process of innovation. Moreover, when the speaker says something, it is important to the listener respect to make redefinition what the speaker meant by the utterance. In addition, Yule (1966) states that pragmatics concerned on the study of meaning as communicated by the speaker (or writer) and interpreted by listener (or reader). Because there is some interpretation by the listeners or readers, it needs to be aware what the speaker means exactly. Pragmatic includes speech acts, presuppositions, and deixis.

One of pragmatic type is a deixis. Deixis always found in our daily communication or in text. A deictic expressions (or deixis) is a word or phrase (such as this, that, these, those, now, then) that points to the time, place, or situation in which a speaker is speaking. Deixis is part of pragmatics study. The term deixis applies to the use of 
expressions in which the meaning can be traced directly to features of the act of utterance; when and where it takes place, and who is involved as speaker and as addresser. Levinson (1983) states that deixis is the single obvious way in which the relationship between language and context is reflected in the structure of themselves. Levinson divided deixis theory into five types: person deixis, time deixis, place deixis, discourse deixis, and social deixis.

Deixis found not only in everyday life, but also in AlQur-an. Al-Qur'an is word of Allah, which he revealed to Muhammad in wording and meaning and has been preserved in the mushafs, and has reached us by mutawaatir transmissions. Al- Qur'an is Holy Scripture for Moslem which has important roles for them. AlQur'an is the communication between God and His believers. Communication is process of carrying messages of which the speaker and hearer should understand it. Al-Qur'an is a communication device that uses written language. Every person who reads the holy Qur'an should understand because Allah has made it easier to learn.

Allah has made Al-Qur'an easier for learning. Learning consist of reading, understanding, memorizing and practicing. Allah has repeat that verse four times in Al-Qur'an. All will be found in surah Al-Qamar. This case tells human that Allah really made Al-Qur'an easier to learn.

Occasionally, when reading Al-Qur'an, the readers can find the the meaning of the words that make confuse. As explanation before, the readers can understand about the meaning easier if the readers know about the context. The reseacher conduct the research on surah Al-Mulk. Surah Al-Mulk is the sixty seventh surah in Al-Qur'an after surah At-Tahrim. Surah Al-Mulk was revealed in Mecca on different occasions. There are 30 verses in this Surah. And it is the the first surah in Juz 29. This surah called Al-Mulk which is mean a The Kingdom.

The researcher conduct the analysis only in selecting verse to make deeper analysis. In this research, the researcher focused the research on surah Al- Mulk from verse 1-30. Surah Mulk stresses that no one can force his will on another; he can only direct and set an example. Surah Mulk takes its name from the very first sentence. Surah Mulk draws attention to the expanse and subtlety of creation as a Sign for the majesty and power of the allCompassionate.

Some examples In English translation surah Al-Mulk verse 1-7: Blessed is He in Whose Hand (Power) is the Dominion, and He is Omnipotent. (1) It is He Who has created death and life that He may try you which of you is best in deed. And He is the All-Mighty, the OftForgiving. (2) It is He Who has created skies in seven layers. You see no disharmony in the creation of the AllMerciful. So turn your gaze (look again), do you see any rift (crack)? (3) Then turn back your look two more times. Your look shall come (back) to you weakened and fatigued. (4) And certainly We have adorned the world's sky with candles and We have made them rocks for the satans (to be thrown at them). And We have prepared for them the torment of the blazing Fire. (5) And for those who deny theirLord is the Torment of Hell. And how evil as a destination. (6) When they were cast therein (in hell), they heard the scary boiling (roaring) sound of it. (7)

The words "He and we" it refers to personal deixis which means is Allah. The words "them and they" it refers to personal deixis which means is creature. The words "the world's sky, in hell" it refers to place deixis point to world which reference to a location.The words "two more times" it refers to time deixis which means is repetition of time. The words "those" it refers to discourse deixis which means is unbelievers. The words "Omnipotent, the All-Mighty, the Oft-Forgiving, the AllMerciful and Lord" it refers to social deixis which means is Allah.

In this research, the researcher chose the English translation of the holy Al-Qur'an by Muhammad Marmaduke William Pickthall to get deeper analysis from one source. Muhammad Marmaduke William Pickthall was an old translator. He was a British Muslim who is best remembered as one of the earliest translator of the Holy Qur'an in English also a Western Islamic scholar noted for his English translation of the Qur'an (1930). He known as one of the translators of the holy Qur'an into English and British convert to Islam. He is regarded as an orthodox, mainstream, Sunni Muslim. In 1930, Pickthall published his English translation of the Qur'an with the title "The Meaning of the Glorious Koran". The translation was authorized by the Al- Azhar University and the Times Literary Supplement praised his efforts by writitng "noted translator of the glorious Qur'an into English language, a great literary achievement. That's all the reason why the researcher picks the English translation of the holy Qur'an by Muhamad Marmaduke William Pickthall.

However, by analyzing this Surah will be an interesting way to applicate all of knowledge that the researcher got during the lectures. It also can help the reader to understand the context about and make the interpretation of some word, since the reference always change. And to know who, where, and when the speech of the speaker.

By this research, deixis can be used in teaching and learning of education. The teacher or lecturer can take examples of deixis from holy Qur'an. They also can used deixis for explain simply in grammar subject. Since in grammar found some term of deixis types. As a teacher, this research very usefull for the researcher. This research enrich teacher knowledge also the teacher can apply it in teaching of grammar. 
The aims to investigate the types of deixis that used in the holy quran surah Al-Mulk translated by Muhammad Marmaduke William Pickthall.

\section{THEORETICAL FRAMEWORK}

Yule (1996) states that deixis is a technical term (from Greek) from one of the most basic things we do with utterances. It means 'pointing via language'. Any linguistic form used to accomplish this pointing is called a deictic expression. And deictic expression sometimes also are called indexicals. Additionally, according to Grundy (2003), deictic means the lexical items which encode context. There are so many example of deixis that usually used in daily activity, such as when we talk about certain object or someone or whoever who talk with us, we often pointing the object via language such as 'this', 'that', 'you', 'them', and etc. It means that unconsciously we often use deixis every time when pointing something.

Moreover, Levinson (1983) states that essentially, deixis concerns the ways in which languages encode or grammaticalize features of the context of utterance or speech event, and thus also concerns ways in which the interpretation of utterances depends on the analysis of that context of utterance. From Levinson's statement, we can take a point that to interpret the real meaning of the deixis that used, we have to concern on the certain context or situation about who is speech, what is the object, who are the addressee or audiences and other contextual aspect based on the speech event. In addition, Levinson (1983) also explain that deixis belongs within the domain of pragmatics, because it directly concerns the relationship between the structure of languages and the contexts in which they are used.

Lyons (1981) defined pragmatics as "the study of actual utterances; the study of use rather than meaning; the study of that part of meaning which is not purely truth-conditional; the study of performance rather than competence." Lyons here concentrated on the user and the context of language use rather than on meaning, grammar or truth.

Also Crystal (2008) stated that pragmatics is the study of communicative actions in its socio-cultural context. Thus, he defined pragmatics as "the study of the principles governing the communicative use of language, especially as encountered in conversations-principles which may be studied as putative universals, or restricted to the study of specific languages."

To sum up, pragmatics is the study of language used for the purposes of communication and the study of what the speakers mean when they produce utterances, by depending on the context rather than on literal meaning of the words.
According to Imai (2009), in the literature there have been three traditionally recognized categories based on three axes, namely spatial-socio-temporal axes. Spatial deixis is categorized based on spatio-axes, (e.g., this, that, here, and there). Then, personal deixis is categorized based on socio-axes (e.g., I and you). And the last is temporal deixis is categorized based on temporal axes (e.g., now, today, and yesterday). In other hand, Levinson (1983) explain that beside three traditional categories of deixis, there are two more categories of deixis called discourse or text deixis and social deixis. Based on explanation above, we can take points that there are three basic types of deixis as traditionally, those are person deixis to point or indicate people or things, then place deixis or spatial deixis to point or indicate location and time deixis or temporal deixis to point or indicate the time signal, also there are two more categories based on Levinson's theory, those are discourse deixis that indicate texts or stories and social deixis that indicate certain realities of social situation.

Person deixis is the type of deixis that indicate to the people, and sometimes it refers to pronoun. According to Levinson (1983), personal deixis concerns the encoding of the role of participants in the speech event in which the utterance in question is delivering. From Levinson's explanation, we can take the main point of person deixis that is refers to the participants in speech event. In this case participants means the speaker and also the addressee.

Place deixis or sometimes called spatial deixis basically is the kind of deixis that indicate a space or pointing such types of location. According to Levinson (1983), place deixis concerns the encoding of spatial location relative to the location of the participant of the speech event. In this case there are two types of distance that can indicate the reference of place deixis, called proximal and distal. Proximal means 'close to the speaker' and distal means 'away from speaker'. Additionally, Levinson (1983) also states that place deixis concerns the specification of location relative to anchorage points in the speech event. As simply, place or spatial deixis refers to indicate the location of the speaker or location that that are showed by the speaker.

The third type of deixis is time deixis. Time deixis is the kind of deixis that indicate about the time or pointing the time via language. Time deixis can also called as temporal deixis. According to Levinson (1983), time deixis concerns the encoding of temporal points and spans relative to the time at which the utterance was spoken (or a written message inscribed).

According to Levinson (1983), discourse deixis has to do with the encoding of reference to portions of the unfolding discourse in which the utterance (which including the text referring expression) is located. Moreover, Levinson (1983) explain that discourse.or text, deixis concerns the use of expressions within some 
utterances to refer to some portion of the discourse that contains that utterance (including the utterance itself). As simply, discourse deixis can be defined as the types of deixis that indicate the location in the discourse or text.

The last types of deixis called social deixis. According to Levinson (1983), social deixis concerns that are relative to participant-roles, particularly aspect of the social relationship holding between speaker and addressee(s) or speaker and some referents. Moreover, Fillmore (1975) explain that social deixis concerns to the aspect of sentences in which reflect or establish or are determined by certain realities of the social situation in which the speech act occurs. Social deixis is related to the social aspect of the speaker and the addressee, such as between a speaker or addressee with higher social status versus speaker or addressee with the lower social status.

The Qur'an, is the main holy book in Islam, which Muslims believe that this book was sent down by God, (Arabic: الله Allah) to the Prophet Muhammad. This book is divided into several chapters and each chapter is divided into several verses.

Surah Al-Mulk ("Kingdom") is the 67th chapter of the Qur'an. This surah is classified as a Makkiyah letter, consisting of 30 verses. It is named Al Mulk which means Kingdom taken from the word Al Mulk which is found in the first verse of this letter. This letter is also called At Tabaarak which means Most Holy.

Muhammad Marmaduke William Pickthall was an old translator. He was a British Muslim who is best remembered as one of the earliest translator of the Holy Qur'an in English also a Western Islamic scholar noted for his English translation of the Qur'an in 1930. He known as one of the translators of the holy Qur'an into English and British convert to Islam.

\section{METHOD}

Based on the research study and theory, this research will be conducted by using descriptive qualitative research method which is presented in qualitative way and the field of language research is in linguistic field. Qualitative design will be used because the data collected in the research were description. The types of deixis and find the meaning of context related to the sentence will be analyzed in this research.Qualitative method refers to research procedure which deals with descriptive data: peoples own written or spoken words and behaviour (Bogdan and Taylor, 2003).

Bogdan (1992) stated the data collected have been term soft, which is rich in description of people, places, and conversations, and not easily handled by statistical procedures. So, the data of this study are words (English translation of surah Al-Mulk translated by Muhammad Marmaduke William Pickthall). Surah AlMulk is the 67th surah in Al-Qur'an (includes 30 verses). This surah provides the crucial thing for muslims and covers the whole content of Al Quran. The source of data in this study is the holy Quran.

In this research, the technique for collecting the data is document analysis. Document analysis is documents that are interpreted by the writer to give voice and meaning around an assessment topic (Jack et al, 1932). The document analysis of this research is Al-Qur'an.

For collecting the data the writer takes all the data (the translation of surah Al-Mulk from Al-Quran) and make sure the data was complete.

The technique of analyzing data in this research are: 1) Data managing, 2) Reading the script, 3) Describing, 4) Classifying the data, and 5) Interpreting the data.

\section{RESULT AND DSICUSSIONS}

\subsection{Findings}

All five type of deixis can be found in the translation of surah Al-Mulk, such as person deixis (frequency 109), place deixis (frequency 13), time deixis (frequency 15), discourse deixis (frequency 11), and soacial deixis (frequency 21). The most types of deixis that occur is person deixis.

Table 1. Five type of deixis can be found in the translation of surah Al-Mulk

\begin{tabular}{|l|l|l|}
\hline No. & Types of Deixis & Frequency \\
\hline 1. & Person & 109 \\
\hline 2. & Place & 13 \\
\hline 3. & Time & 15 \\
\hline 4. & Discourse & 11 \\
\hline 5. & Social & 21 \\
\hline
\end{tabular}

\subsection{Discussions}

Based on the finding, there are 169 frequency which are included the types of deixis which are the objects of research contained in translation of surah Al-Mulk. 169 quotations included in the forms of the deixis types include: person, place, time, discourse and social.

\section{CONCLUSION}

The researchers concludes that there are all types of deixis in the translation of surah Al-Mulk such as person, place, time, discourse and social. It found from the translation of surah Al-Mulk by Muhammad Marmaduke William Pitckhall. The most types of deixis that occur is person deixis.

\section{REFERENCES}

[1] Bogdan, R. C. 1992. Qualitative Research for Education. California: Pearson A\&B 
[2] Creswell, John W. 2007. Educational Research: Planning, Conducting and Evaluating Quantitative and Qualitative Research-4th ed. Boston: Pearson Education.

[3] Cruse, A. 2006. A Glossary of Semantics and Pragmatics. Edinburgh: Edinburgh University Press

[4] Crystal, David. 2008. A Dictionary of Linguistics and Phonetics. Sixth Edition. Oxford: Blackwell Publishing Ltd

[5] Fillmore, J. Charles. 1971. Santa Cruz Lectures on Deixis. Berkeley: University of California

[6] Fillmore, J. Charles. 1975. Santa Cruz Lectures on Deixis. Berkeley: University of California

[7] Fromkin, Victoria et.al. 2003. An Introduction to Language: Seventh Edition. United States: Thomson Wadsworth.

[8] Grundy, Peter. 2003. Doing Pragmatics. New York: Oxford University Press

[9] Levinson, Stephen C. 1983. Pragmatics. Cambridge: Cambridge University Press

[10] Lincoln, Y. S. \& Guba, E. G. 1985. Naturalistic Inquiry. Newbury Park, Ca: Sage Publications.

[11] Lyons, J. 1981. Language and Linguistics. Cambridge: Cambridge University Press

[12] Lyons, J. 1977. Semantics. Cambridge: Cambridge University Press

[13] Lincoln and Guba. 1985. Qualitative Research in Linguistic and Language Teaching. Beverly Hills: California.

[14] Mey, Jacob. 2009. Concise Encyclopedia of Pragmatics. Amsterdam: Elsevier Science

[15] Moekijat. 1993. Teori Komunikasi. Bandung: Mandar Maju

[16] Steven J. Taylor, Robert Bogdan. 2003. Introduction to Qualitative Research Methods: A Guidebook and Resource. US: John Wiley \& Sons

[17] Visconti \& Hansen, Crítica de. 2009. Current Trends in Diachronic Semantics and Pragmatics. Nieves Hernández-Flores: Universidad de Copenhague.

[18] Yule, George. 1985. The Study of Languge. New York: Oxford University Press

[19] Yule, George. 1996. Pragmatics. New York: Oxford University Press 